\title{
Developmental Changes in the Milk Fat Globule Membrane Proteome During the Transition from Colostrum to Milk ${ }^{1}$
}

\author{
T. A. Reinhardt ${ }^{2}$ and J. D. Lippolis \\ Periparturient Diseases of Cattle Research Unit, USDA, Agricultural Research Service, National Animal Disease Center, Ames, IA 50010
}

\begin{abstract}
Shotgun proteomics, using amine-reactive isobaric tags (iTRAQ), was used to quantify protein changes in milk fat globule membranes (MFGM) that were isolated from d 1 colostrum and compared with MFGM from d 7 milk. Eight Holstein cows were randomly assigned to 2 groups of 4 cow sample pools for a simple replication of this proteomic analysis using iTRAQ. The iTRAQ labeled peptides from the experiment sample pools were fractionated by strong cation exchange chromatography followed by further fractionation on a microcapillary high performance liquid chromatograph connected to a nanospray-tandem mass spectrometer. Data analysis identified 138 bovine proteins in the MFGM with 26 proteins upregulated and 19 proteins downregulated in d 7 MFGM compared with colostrum MFGM. Mucin 1 and 15 were upregulated greater than 7-fold in MFGM from d 7 milk compared with colostrum MFGM. The tripartite complex of proteins of adipophilin, butyrophilin, and xanthine dehydrogenase were individually upregulated in $\mathrm{d} 7 \mathrm{MFGM}$ 3.4-, 3.2-, and 2.6-fold, respectively, compared with colostrum MFGM. Additional proteins associated with various aspects of lipid transport synthesis and secretion such as acyl-CoA synthetase, lanosterol synthase, lysophosphatidic acid acyltransferase, and fatty acid binding protein were upregulated 2.6- to 5.1-fold in $\mathrm{d} 7$ MFGM compared with colostrum MFGM. In contrast, apolipoproteins A1, C-III, E, and A-IV were downregulated 2.6- to 4.3-fold in d 7 MFGM compared with colostrum MFGM. These data demonstrate that quantitative shotgun proteomics has great potential to provide new insights into mammary development.
\end{abstract}

Key words: milk fat globule membrane, proteomics, mammary gland, mastitis

\footnotetext{
Received December 16, 2007.

Accepted February 14, 2008.

${ }^{1}$ Disclaimer: Mention of trade names or commercial products in this article is solely for the purpose of providing specific information and does not imply recommendation or endorsement by the USDA.

${ }^{2}$ Corresponding author: tim.reinhardt@ars.usda.gov
}

\section{INTRODUCTION}

Proteomics is a tool that will help identify proteins important to milk production and secretion. Identification of proteins associated with various aspects of milk production and secretion will provide a foundation for new research in lactation biology. Most of proteomic studies conducted thus far on mammary epithelial cells, organelles, membranes, and the secretion processes are focused on breast cancer, rodent lactation, or both (Wu et al., 2000a,b; Quaranta et al., 2001; Charlwood et al., 2002; Pucci-Minafra et al., 2002; Fortunato et al., 2003; Jacobs et al., 2004; Davies et al., 2006). Although these studies have advanced our understanding of mammary function and milk secretion, they may not address the unique aspects of milk secretion in dairy cattle. Recently, 2 papers on bovine mammary proteomics have appeared (Daniels et al., 2006; Reinhardt and Lippolis, 2006). The first paper examined mammary protein expression in growing virgin heifers (Daniels et al., 2006), and the second was a survey of proteins expressed in milk fat globule membranes (Reinhardt and Lippolis, 2006).

Our understanding of the molecular mechanisms critical to milk fat secretion is incomplete (Mather and Keenan, 1998a,b; Keenan, 2001). The scarcity of information is due in large part to the lack of cell lines that secrete milk and milk fat (Keenan, 2001). The MFGM is a rich source of membrane proteins, and proteomic analysis of these membranes has highlighted some of the possible signaling and secretory pathways used by the mammary gland (Reinhardt and Lippolis, 2006). Furthermore, the proteome of the MFGM provides additional insight into this membrane's cellular origin. The most widely accepted source of membrane for the MFGM is the apical membrane of the secretory cell (Mather and Keenan, 1998a; Keenan, 2001). Their conclusions are supported by biochemical, electron microscopy, and immunocytochemical evidence.

The major proteins in the MFGM have been identified using traditional biochemical approaches (Mather, 2000). These methods are slow, laborious, and address only one protein at a time. Proteomic and microarray approaches can identify gene and protein 
connections to a pathway that is not apparent or predictable from biochemical and genetic analysis of a biological system (Patterson and Aebersold, 2003). This approach has been applied widely to quantitative proteomics (Ross et al., 2004; DeSouza et al., 2005; Chen et al., 2006; Hu et al., 2006; Keshamouni et al., 2006; Lippolis et al., 2006) and overcomes many of the problems of 2-dimensional electrophoresis in the study of membrane proteins (Gu et al., 2003; Peirce et al., 2004; Lippolis et al., 2006).

We used a shotgun proteomics approach using amine-reactive isobaric tags (iTRAQ) to quantify protein changes in milk fat globule membranes (MFGM) that were isolated from d 1 colostrum compared with d 7 milk. Our objective was to examine how the transition from colostrum secretion to milk secretion changes protein expression in MFGM.

\section{MATERIALS AND METHODS}

\section{Animals and Milk Fat Membrane Preparation}

Colostrum or milk was collected from 8 Holstein cows at parturition and $\mathrm{d} 7$ of lactation. The colostrum or milk from each collection was brought immediately to the lab and centrifuged at $10,000 \times g$ for $15 \mathrm{~min}$ at $4^{\circ} \mathrm{C}$. The floating milk fat pellet was removed, mixed with 10 volumes of ice-cold phosphate buffered saline $(\mathrm{pH} 7)+$ complete protease inhibitor cocktail from Boehringer Mannheim (Indianapolis, IN), and centrifuged at $10,000 \times g$ for $15 \mathrm{~min}$. This washing step was repeated 3 times until the supernatant was clear (Reinhardt and Lippolis, 2006).

The MFGM were prepared from the washed milk fat as previously described (Reinhardt et al., 2000; Prapong et al., 2005; Reinhardt and Lippolis, 2006). Washed milk fat from colostrum or milk was diluted in 10 volumes of buffer A, which contained Tris-HCL (10 $\mathrm{mM}), \mathrm{MgCl}_{2}(2 \mathrm{mM})$, phenylmethylsulfonyl fluoride $(0.1 \mathrm{~m} M)$, EDTA $(1 \mathrm{~m} M), 4 \mu \mathrm{g} / \mathrm{mL}$ of aprotinin, and $4 \mu \mathrm{g} / \mathrm{mL}$ of leupeptin at $\mathrm{pH}$ 7.5. The sample was homogenized using a Polytron PT-10 homogenizer (Brinkman Instruments, Boston, MA) running at $12,000 \mathrm{rpm}$. Each homogenization step was for $12 \mathrm{~s}$ with $30 \mathrm{~s}$ of sample cooling between each homogenization run. A total of three 12-s homogenizations were performed on the sample. The homogenate was mixed with an equal volume of buffer B (buffer A plus 300 $\mathrm{m} M \mathrm{KCl}$ ) and centrifuged at $100,000 \times g$ for $1 \mathrm{~h}$. The supernatant was discarded and the membrane pellet was resuspended in buffer C (buffer A plus $150 \mathrm{mM}$ $\mathrm{KCl}$ ) (Reinhardt et al., 2000). The resuspended membrane preparation was centrifuged at $100,000 \times g$ for $1 \mathrm{~h}$. The supernatant was discarded and MFGM pellet was resuspended in buffer A. Protein concentration was determined using the BioRad Protein Assay Kit using a BSA standard. The MFGM were stored at $-70^{\circ} \mathrm{C}$ until needed.

\section{Extraction of Extrinsic Proteins to Concentrate MFGM Intrinsic Proteins}

The MFGM prepared as described above were pelleted by centrifugation at $100,000 \times g$ for $1 \mathrm{~h}$. All procedures were done at $4^{\circ} \mathrm{C}$. The membrane pellet was resuspended in a small amount of $300 \mathrm{~m} M$ sucrose, 10 $\mathrm{m} M$ Tris-HCL at $\mathrm{pH}$ 7.5. This suspension was diluted with ice-cold $0.1 M$ sodium carbonate ( $\mathrm{pH} 11.5$ ) to a protein concentration $0.01 \mathrm{mg} / \mathrm{mL}$ (Fujiki et al., 1982; Reinhardt and Lippolis, 2006). The sample was incubated on ice for $1 \mathrm{~h}$ to extract extrinsic proteins and then centrifuged at $100,000 \times g$ for $1 \mathrm{~h}$ through a cushion of $300 \mathrm{~m} M$ sucrose (10\% of the tube volume). The MFGM intrinsic protein pellet was resuspended in buffer A. Protein concentration was determined, and the extracted MFGM were stored at $-70^{\circ} \mathrm{C}$ until needed. This procedure enriched the MFGM preparation for intrinsic proteins by reducing but not eliminating extrinsic protein content.

\section{Sample Preparation for Mass Spectroscopy Analysis}

Samples were randomized, and 4 sample pools were created (Figure 1). One hundred micrograms of protein from each sample pool was dried and processed as follows. Membrane proteins from the 4 samples were each resuspended in $50 \mu \mathrm{L}$ of $25 \mathrm{mM}$ triethyl-ammonium bicarbonate $(\mathrm{pH} 8)$ in $1.5-\mathrm{mL}$ microcentrifuge tubes. After adding cap locks, the proteins were thermally denatured at $90^{\circ} \mathrm{C}$ for 20 min as described (Park and Russell, 2000, 2001). The samples were then cooled on ice for $10 \mathrm{~min}$ and then dried in a vacuum centrifuge. For trypsin digestion, $25 \mu \mathrm{L}$ of proteomicgrade trypsin $(20 \mu \mathrm{g} / \mathrm{mL}$ in $25 \mathrm{~m} M$ triethyl-ammonium bicarbonate) was added to each sample. We added acetonitrile (ACN) so that the solution was $30 \%$ ACN (Russell et al., 2001). This ACN/trypsin solution was incubated at $37^{\circ} \mathrm{C}$ overnight. The next day the samples were cooled to room temperature and then dried in a vacuum centrifuge. The samples were stored dry at $-20^{\circ} \mathrm{C}$ until used.

Each sample was then labeled using the iTRAQ kit for amine-modifying labeling reagents for multiplexed relative and absolute protein quantitation (Applied Biosystems, Foster City, CA). See Figure 1 for the sample analysis work flow. The iTRAQ-labeled peptides were dried and resuspended in $300 \mu \mathrm{L}$ of $20 \mathrm{mM}$ formic acid and $20 \% \mathrm{ACN}$ ). Samples were run on a 


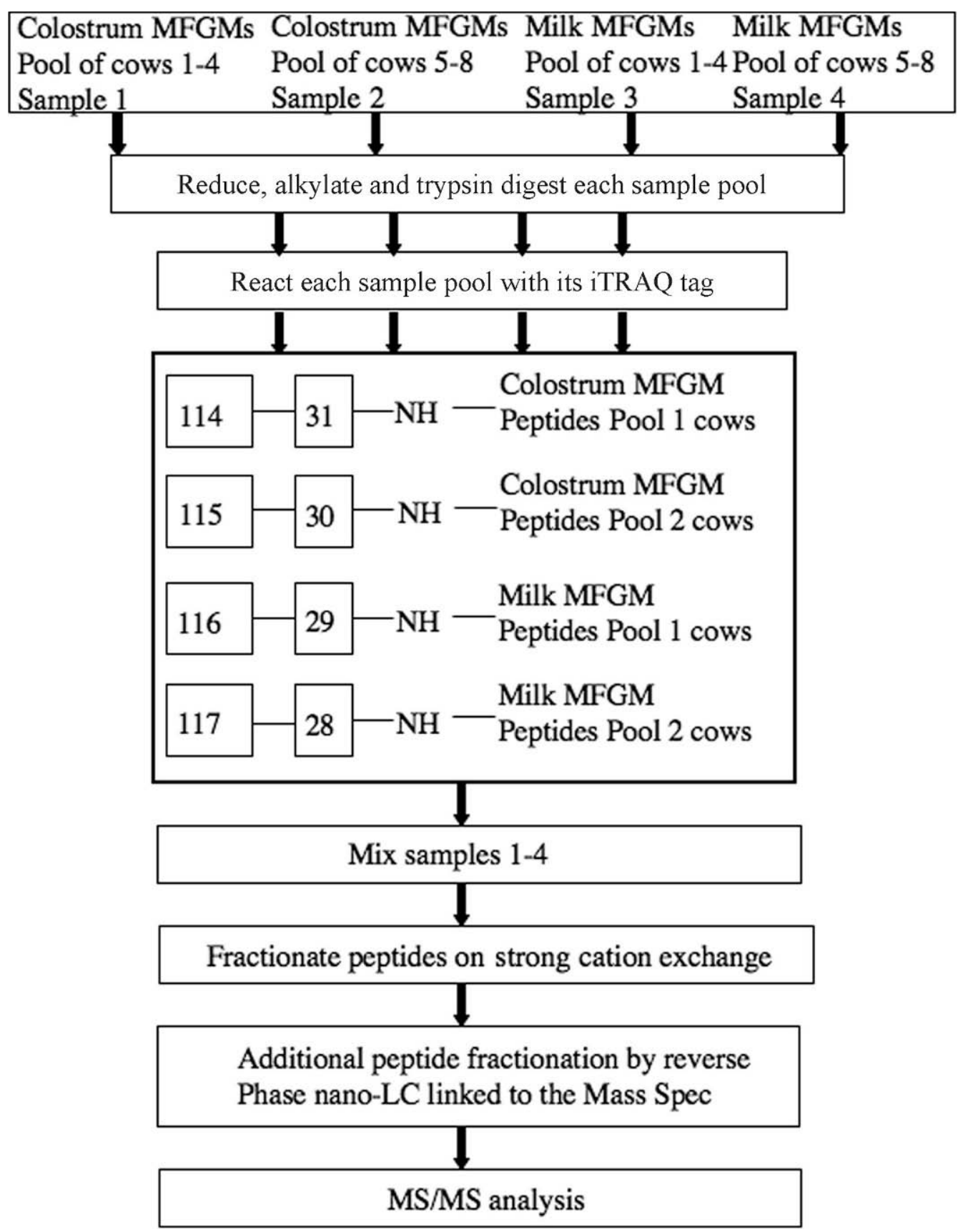

Figure 1. Experimental workflow. MFGM = milk fat globule membrane

strong cation exchange (SCX) column (Mono S PC 1.6/ 5; Amersham, Piscataway, NJ) with a gradient of solution A (20 mM formic acid; $20 \% \mathrm{ACN}, \mathrm{pH} 2.7)$ and solution B (20 mM formic acid; $20 \%$ ACN; $350 \mathrm{mM}$ ammonium bicarbonate, $\mathrm{pH} 4.7$ ). Sample fractions ( 0.5 $\mathrm{mL}$ ) were collected over a 15 -min gradient of 0 to $35 \%$ solution B followed by 1.5 min in $90 \%$ solution B. Sample fractions were dried down and resuspended in 30-
$\mathrm{mL} 0.1 \%$ formic acid in 5\% ACN (Lippolis and Reinhardt, 2005; Lippolis et al., 2006).

\section{HPLC and Tandem Mass Spectroscopy of the Samples}

Each SCX fraction was analyzed by capillary HPLC (CapLC; Waters, Milford, MA) in line with a Q-TOF 
Ultima API mass spectrometer (Waters). An Altantis $\mathrm{C}_{18}$ NanoEase column $(75 \mathrm{~mm} \times 100 \mathrm{~mm})$ was used for peptide separation. The system was configured to concentrate and wash the injected sample on a Symmetry $300 \mathrm{C}_{18}$ precolumn. Seven minutes after the start of sample loading, the precolumn was switched in line with the analytical column to allow the trapped peptides to be eluted onto the analytical column. Mobile phase A was $0.1 \%$ formic acid in 5\% ACN. Mobile phase $\mathrm{B}$ was $0.1 \%$ formic acid in $95 \% \mathrm{ACN}$. The gradient was 95\% A for 5 min and then ramped linearly to $60 \% \mathrm{~A}$ over $85 \mathrm{~min}$. Over the next $2.5 \mathrm{~min}$ it was ramped to $10 \% \mathrm{~A}$ and held an additional $10 \mathrm{~min}$ before reequilibration of the column. The flow rate was approximately $300 \mathrm{~nL} / \mathrm{min}$. The analytical column was connected to Waters lockspray-nanospray interface on the front of the mass spectrometer. The lockspray used the peptides [Glu ${ }^{1}$-fibrinopeptide B and leucine enkephalin (Sigma, St. Louis, MO) as mass calibration standards. The capillary voltage was $3,500 \mathrm{~V}$ and was tuned for signal intensity. The 5 most intense ions with charge states between 2 and 4 were selected in each survey scan if they met the switching criteria. Three collision energies were used to fragment each peptide ion based on its mass to charge $(\mathrm{m} / \mathrm{z})$ values. Each fraction was run 4 times, once collecting MSMS data on the full range of parent masses followed by runs collecting MSMS data on parent masses in 3 mass ranges (400 to 635,635 to 750 , and 750 to 1,500; Lippolis et al., 2006) for a total 112 runs.

\section{Protein Identification}

All MS data files were processed into pkl files using ProteinLynx Global Server 2.0 (Waters, Milford, MA) and lock-spray correction of MS data with [Glu]-fibrinopeptide B and MSMS with leucine enkephalin. The pkl files were merged into a single file using the program Merge (Matrix Science, London, UK). The data were then analyzed with Mascot (Matrix Science) using the NCBI NR protein database with mammalia taxonomy, MMTS (C), iTRAQ (K), and iTRAQ (N-term) as fixed modifications, and iTRAQ (Y) and oxidation (M) as variable modifications. The peptide tolerance was $20 \mathrm{ppm}$ and the MSMS tolerance was $0.05 \mathrm{Da}$. The Mowse scoring algorithm (Pappin et al., 1993) in Mascot was used to determine the probability that a protein was correctly identified. We used $P<0.05$ for protein identity and a Mowse score greater than 41 yields a $P<0.05$ protein identity. Abundance data were obtained by determination of the peak area of each of the iTRAQ labels after the peak was smoothed and centroided. Data were extracted from the Mascot.dat file with a Perl script that parsed peptide data including the abundance numbers for iTRAQ daughter ion peaks within $a \pm 0.05$ Da tolerance. Data were manually organized to remove duplication of query assignments and duplicate proteins. All proteins without at least two MSMS spectra with a probability of a correct match greater than 95\% were removed. Only MSMS spectra with abundance information for all 4 iTRAQ labels were retained. Relative changes in protein expression were calculated in the same way as described by Ross et al. (2004). Briefly, the abundance of the iTRAQ label used to tag either the colostrum MFGM sample pool 1 was divided by the sum of the abundance of the colostrum MFGM sample pool $1+d 7$ MFGM sample pool 1. The range of this calculation is between 0 and 1 with result of 0.5 meaning no change in protein expression. So a low Ross ratio indicated up-regulation and a high Ross ratio indicated down-regulation in $d$ 7 MFGM compared with colostrum MFGM. The procedure was use for the simple replicate data for sample pool 2. The mean Ross calculation for all MSMS spectra for these simple replicate samples was 0.52 with a standard deviation of 0.14 . A change was considered real if the average iTRAQ calculation of a protein was outside the range of the total MSMS Ross ratio plus or minus the standard deviation (Ross et al., 2004), which for these data equates to Ross ratios of 0.38 to 0.66 .

\section{Gel Electrophoresis and Western Blotting}

The MFMG proteins from individual cows were incubated for 5 min at $95^{\circ} \mathrm{C}$ in a modified Laemmli buffer containing $150 \mathrm{mg} / \mathrm{mL}$ urea and $65 \mathrm{mM}$ DTT. Equal volumes of sample were loaded into 2 wells of an 8 to $16 \%$ Tris-glycine gradient gels (Novex, San Diego, CA) and electrophoresed for $1.5 \mathrm{~h}$ at $125 \mathrm{~V}$. Proteins were transferred to nitrocellulose membranes for $75 \mathrm{~min}$ at $25 \mathrm{~V}$ in $0.192 M$ glycine, $0.025 M$ Tris at $\mathrm{pH} 8.3$ (Reinhardt et al., 2004a,b). All antibodies were diluted according to manufacturer's instructions. Antibodies to xanthine oxidase (ab6194), syntaxin 3 (ab4113), and actin (ab8226) were purchased from Abcam (Cambridge, MA). SNAP23 (Pai-738) antibody was purchased from Affinity BioReagents (Golden, CO). The bovine TLR-2 antibody was prepared from the C-terminus peptide using procedures described (Reinhardt et al., 2000). Blots were developed using Pierce's Supersignal (Pierce Products, Rockford, IL) according to the protocol provided by the manufacturer.

\section{RESULTS}

Figure 2 showed a representative 1-DE gel image for the carbonate extracted colostrum and d 7 MFGM 


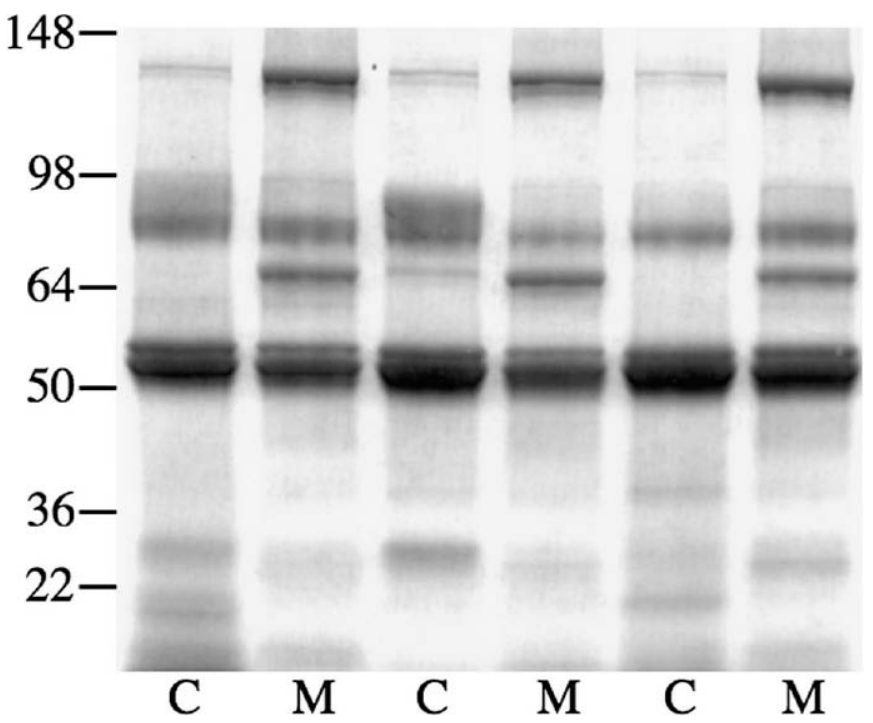

Figure 2. Carbonate-extracted colostrum milk fat globule membranes (MFGM; C) and 7-d milk MFGM separated on an 8 to 16\% SDS-PAGE gel from 3 of the 8 cows used in this study. Each lane represents $25 \mu \mathrm{g}$ of membrane protein with the location of molecular weight markers indicated at the left side of the gel.

for 3 cows. Gross differences in the proteins expressed can be seen between colostrum and d 7 milk MFGM. Using a shotgun proteomics approach outlined in Figure 1, we identified and have expression data for greater than 130 proteins. The false discovery rate for our data was $1.29 \%$ as determined by using a decoy database, thus yielding high confidence in our identification data. Approximately $70 \%$ of the proteins identified are membrane-associated proteins with the remainder being secreted proteins or of cytosol origin. Data analysis identified 26 proteins upregulated and 19 proteins downregulated in d 7 MFGM compared with colostrum MFGM (Tables 1 and 3, respectively). A change was considered real if the average iTRAQ calculation of a protein was outside the range of the average of all MSMS Ross ratios plus or minus the standard deviation (Ross et al., 2004), which for these data equates to Ross ratios of 0.38 to 0.66 (see Materials and Methods section). Table 2 shows proteins considered unchanged using the criteria of Ross. However, the reader will note that the data in Table 2 showing fold changes up, down, or no change are noted based on mean Ross ratios. These data are presented for information only as some of the changes may prove to be real as described for syntaxin 3 and TLR2 below.

Proteins associated with various aspects of lipid transport synthesis and secretion such as acyl-CoA synthetase, lanosterol synthase, lysophosphatidic acid acyltransferase, cell death-inducing DFFA-like effector A, and fatty acid binding protein were upregu- lated 2.6- to 5.1-fold in d 7 MFGM compared with colostrum MFGM (Table 1). The mucin proteins, mucin 1 and 15 , showed the greatest expression change of all the proteins analyzed. Both mucin 1 and 15 were upregulated greater than 7-fold in MFGM from $d 7$ milk compared with colostrum MFGM (Table 1).

Specific proteins involved with vesicle transport and protein trafficking showed variable regulation. Proteins, such as SAR1a gene homolog 1, SNAP-23, synaptosomal-associated protein 29 were upregulated 2- to 3 -fold in MFGM from d 7 milk compared with colostrum MFGM (Table 1). However, many proteins involved in vesicle transport and protein trafficking have borderline expression changes using the criteria of Ross et al., 2004 (Table 2). To examine these proteins further, we performed Western blots (Figure 3) on individual cow samples using antibodies to xanthine dehydrogenase SNAP-23, syntaxin 3, and TLR2, which were shown to be upregulated 2.6-, 3.0-, 1.6-, and 1.7fold, respectively, in MFGM from d 7 milk compared with colostrum MFGM (Tables 1 and 2). Figure 3 (lower panel) shows the comparison results for Western blot data from 8 individuals versus iTRAQ expression results for two 4-cow sample pools. The result compare quite favorably. Syntaxin 3 and TLR2, which appeared to be upregulated in MFGM from d 7 milk compared with colostrum MFGM (Table 2) but did not meet the criteria of Ross et al. (2004) for a change in expression, can be seen in Figure 3. By Western blotting syntaxin 3 and TLR2 were upregulated in MFGM from d 7 milk compared with colostrum MFGM. The Western blot data confirm the validity of the iTRAQ data as well as demonstrating that the Ross criteria for protein expression changes is conservative. This gives the changes noted in Tables 1 and 3 more confidence despite the limitations of proteomic iTRAQ experiments with regard to experiment replicates and suggests that proteins in Table 2 that are up- or downregulated 1.6-fold or greater may be real changes as was found for syntaxin 3 and TLR2 by Western blotting.

As shown in Table 3 secreted proteins such as apolipoproteins A1, C-III, E, A-IV clusterin and lactoferrin were downregulated 2.6- to 4.3-fold in d 7 MFGM compared with colostrum MFGM (Table 3).

\section{DISCUSSION}

Shotgun proteomics in conjunction with iTRAQ protein expression tags were used to identify and measure developmental protein expression changes in the MFGM isolated from colostrum vs. MFGM isolated from milk on $d 7$ of lactation. The goal of this experimental approach is to ultimately make connections 
Table 1. Proteins upregulated in milk fat globule membranes (MFGM) on d 7 compared with colostrum MFGM according to the method of Ross et al. (2004)

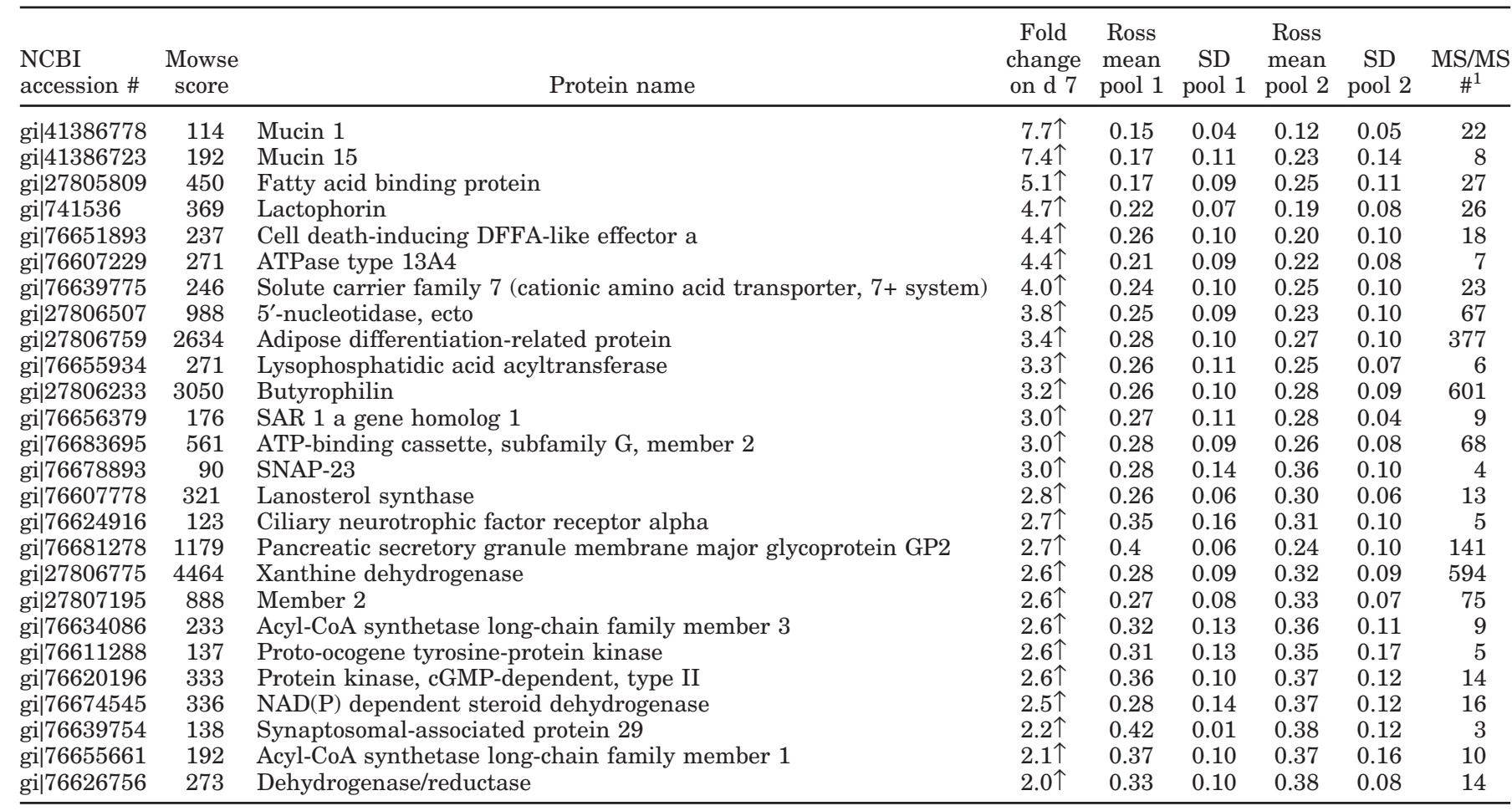

${ }^{1} \mathrm{MS} / \mathrm{MS}$ \# is the number of peptides from this protein that were sequenced in the mass spectrometer and used for identification. For abundant proteins such as "butyrophilin" this number is very large due to repeated sequencing of the same peptides.

between cellular functions and pathways that may not be predictable from traditional biochemical experiments in lactation biology.

The extreme dynamic range seen in protein abundances in general complicates proteomic analysis. It is estimated that cells may contain proteins with as few as 10 copies per cell ranging up to $\sim 1,000,000$ copies per cell (Moritz et al., 2004). For this reason it is important to simplify the proteome before analysis. We did this, in part, by extracting the MFGM with carbonate to remove extrinsic proteins (Fujiki et al., 1982), so we could then focus on a simpler MFGM proteome that was enriched for intrinsic proteins. However, for the bovine MFGM proteome, one of the greatest obstacles to the identification of lower abundance proteins is the abundance of a few MFGM proteins, such as butyrophilin (Mather, 2000). Butyrophilin constitutes 30 to $40 \%$ of the total protein in the Holstein MFGM (Mather, 2000). Due to this dominate protein and its protein partners, adipophilin and xanthine oxidase, excessive peptide signal results in the mass spectrometer missing many coeluting low abundance proteins. Several of these abundant MFGM proteins contribute to this problem in the analysis of the MFGM proteome as they account for $>70 \%$ of the high quality peptides seen by the mass spectrometer in the shotgun MFGM proteome. The consequence of these or any overly abundant proteins in a proteome is simply a reduction in the total number of proteins that can be identified with high confidence. Future advancements into the analysis of less abundant proteins of the MFGM proteome will require specific depletion of high abundant proteins as has been used successfully in blood serum proteomic studies.

A detailed discussion of all the protein changes is beyond the scope of this paper. We will discuss some changes related to fat metabolism, the secretory process and factors important for mammary health, but provide the bulk of the data for building a developmental MFGM proteome database.

The tripartite complex of proteins of adipophilin, butyrophilin, and xanthine dehydrogenase (Heid et al., 1996; McManaman et al., 2002; Vorbach et al., 2002; Ogg et al., 2004) were individually upregulated in $\mathrm{d} 7 \mathrm{MFGM}$ in parallel compared with colostrum MFGM (Table 1). This parallel upregulation is expected for a complex with 3 components fixed in a molar ratio. These proteins and other proteins associated with lipid transport, synthesis, and secretion are upregulated several-fold in d 7 MFGM compared with colostrum MFGM (Table 1), which is indicative of an 
Table 2. Proteins unchanged in milk fat globule membranes (MFGM) on d 7 compared with colostrum MFGM according to the method of Ross et al. (2004) $)^{1}$

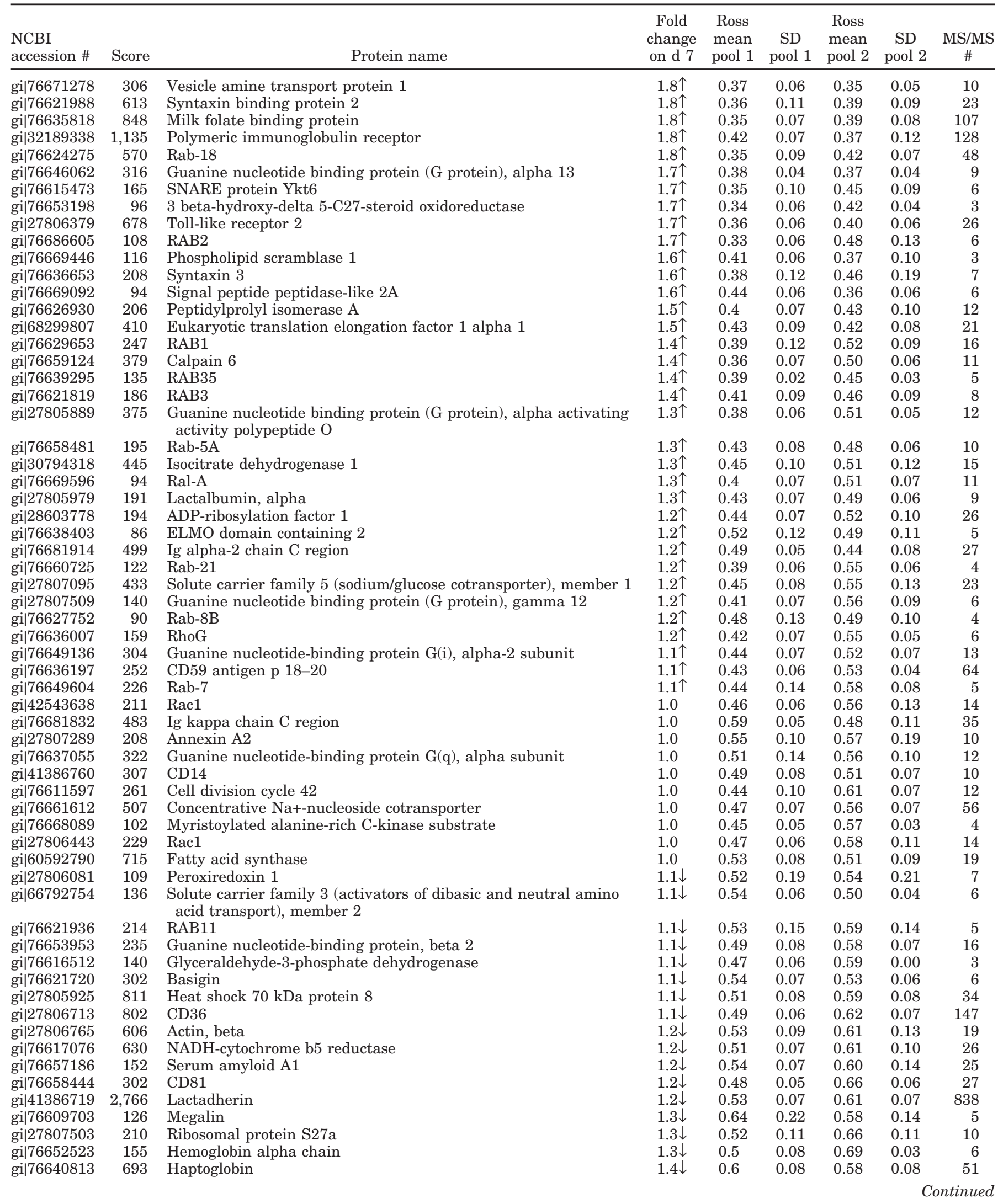


Table 2 (Continued). Proteins unchanged in milk fat globule membranes (MFGM) on d 7 compared with colostrum MFGM according to the method of Ross et al. $(2004)^{1}$

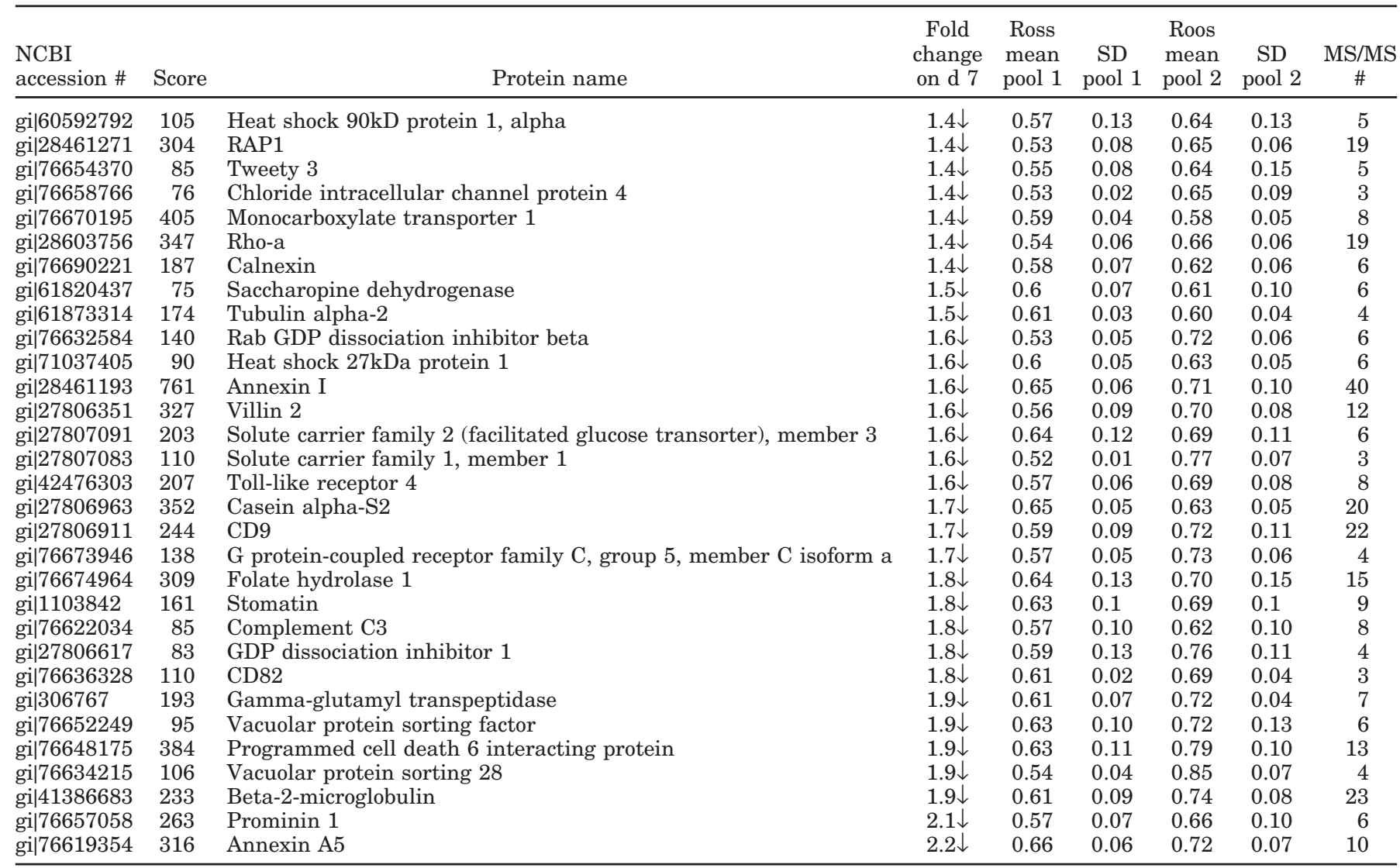

${ }^{1}$ Changes are still noted, and some may be real as discussed.

Table 3. Proteins downregulated in milk fat globule membranes (MFGM) on day compared with colostrum MFGM according to the method of Ross et al. (2004)

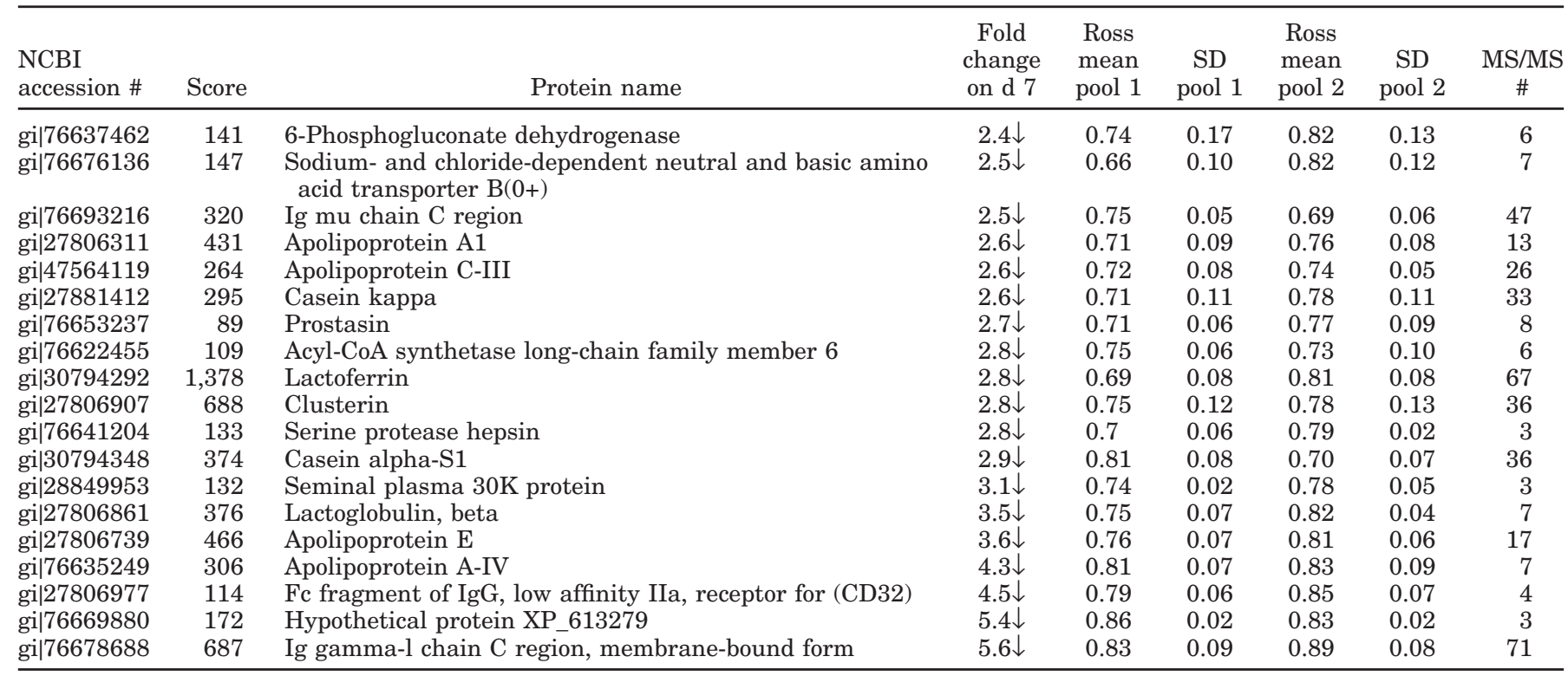




\section{Xanthine dehydrogenase}
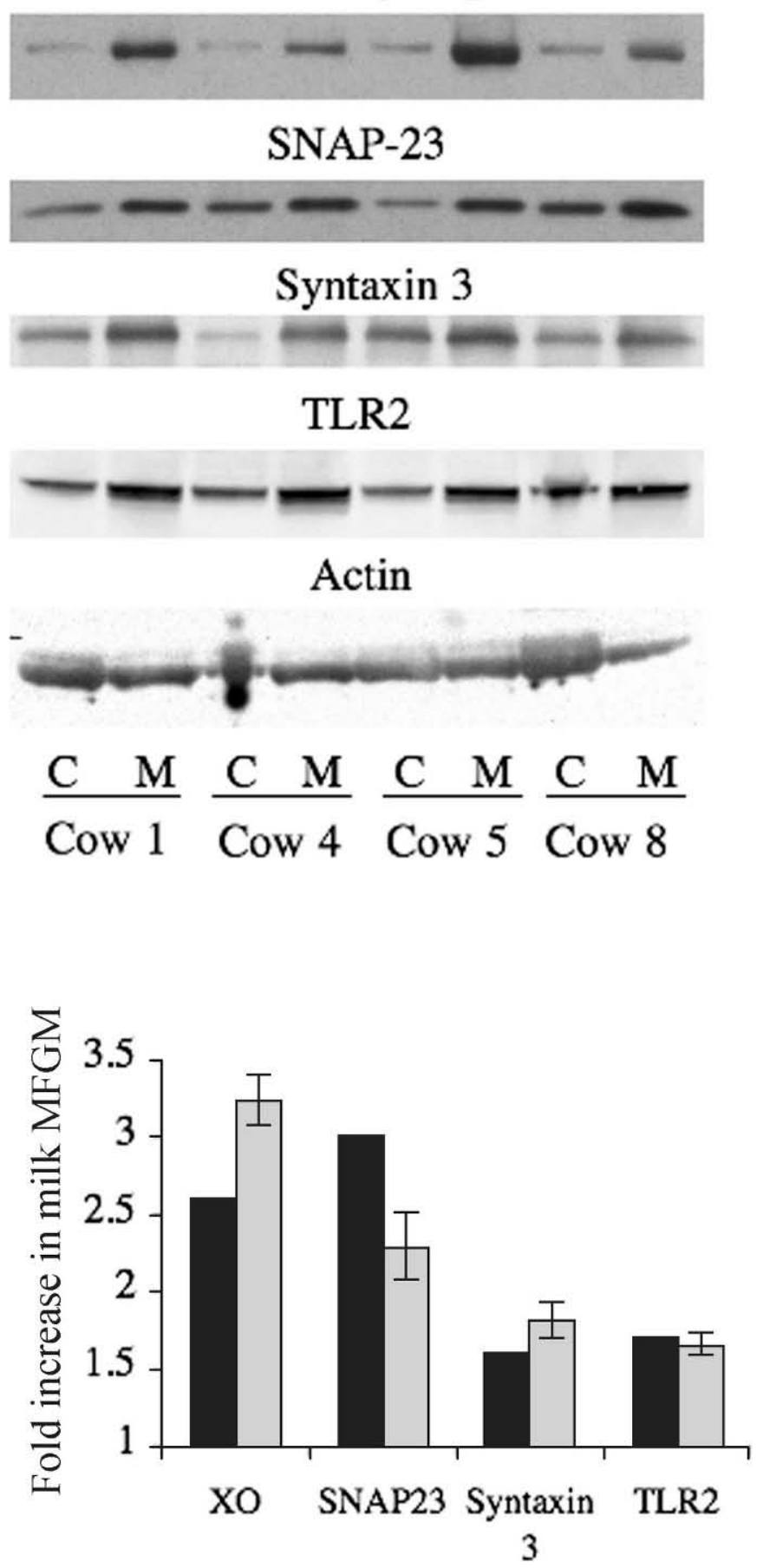

Figure 3. Upper panel: representative Western blots of carbonateextracted colostrum milk fat globule membranes (MFGM; C) and 7d milk MFGM (M) separated on an 8 to 16\% SDS-PAGE gel from 4 of the 8 cows used in this experiment. Cows 1 and 4 are from sample pool 1. Cows 5 and 8 are from sample pool 2. Lower panel: graphical comparison of amine-reactive isobaric tag (iTRAQ) expression data (black bars) compared with Western blot data (corrected for actin expression) from all 8 cows (gray bars). $\mathrm{XO}=$ xanthine dehydrogenase/oxidase. early developmental shift in milk fat transport despite higher fat content in colostrum (Parrish et al., 1950).

The marked upregulation of cell death-inducing DFFA-like effector a (CIDEA) was at first puzzling as it originally identified function was apoptosis (Reed et al., 2003). Subsequent research has shown that CIDEA plays a prominent role in fat energy balance and fatty acid regulation (Zhou et al., 2003; Nordstrom et al., 2005). This protein may therefore be a new example of "gene sharing" as described for xanthine oxidase, where it is both an enzyme important in purine metabolism and separately plays a key role as a membraneassociated protein in association with adipophilin and butyrophilin with a key role in milk fat secretion (Heid et al., 1996; McManaman et al., 2002; Vorbach et al., 2002; Ogg et al., 2004). The identification of CIDEA in the MFGM and its upregulation in d 7 MFGM is an example of the power of proteomics in identifying potential new target proteins for hypothesis-driven research in lactation biology.

We found that some proteins of lipid transport and secretion, such as the lipoproteins, were downregulated in d 7 MFGM compared with colostrum MFGM. These proteins have all been previously associated with the MFGM proteome (Cavaletto et al., 2004), but the reasons for their downregulation at $\mathrm{d} 7 \mathrm{of}$ lactation are currently unknown.

Mather and Keenan (1998b) point out in their review that the general progress in understanding the nature and regulation of milk secretion at the cellular and molecular level has lagged behind the progress in other secretory systems. Furthermore, much of what is proposed is by analogy with other quite different secretory model systems. Using quantitative shotgun proteomics we demonstrated that membrane/protein trafficking proteins were upregulated in MFGM by $\mathrm{d} 7$ or tended to be upregulated.

The Rab proteins are low molecular weight GTPbinding proteins that form the largest branch of the Ras superfamily of GTPases. The Rab proteins and their effectors coordinate various stages of transport in the secretory pathway (Zerial and McBride, 2001). Rab18, which is up 1.8-fold in d 7 MFGM, regulates lipid droplet-associated membrane formation and interacts with adipophilin (upregulated 3.4-fold), which in involved in lipid droplet formation and secretion (Martin et al., 2005; Ozeki et al., 2005; McManaman et al., 2007). Three membrane proteins, SNAP-25, synaptobrevin, and syntaxin, form the core of a ubiquitous membrane fusion machine that interacts with the soluble proteins $N$-ethylmaleimide-sensitive factor (NSF) and a-SNAP. The Rab proteins, in coordination with the core fusion machinery and Munc-18, help to mediate vesicle docking and fusion. The SNAP are 
cytosolic proteins that play a key role in the process of membrane fusion in intracellular vesicle trafficking. In eukaryotic cells, the SNARE (soluble $N$-ethylmaleimide-sensitive factor attachment protein receptor) complex is critical to membrane docking and fusion and is believed to impart some degree of specificity between vesicle SNARE and target organelle SNARE. In neurons and neuroendocrine cells, the SNARE complex consists of the integral membrane proteins VAMP (vesicle-associated membrane protein), syntaxin, and SNAP25. In nonneuronal tissues, such as mammary tissue, SNAP23 functionally replaces SNAP25 in the SNARE complex. Studies show that VAMP, syntaxin, and SNAP23 are required for SNARE function. This complex exists as a heterotrimer of the three proteins (Zerial and McBride, 2001; Bonifacino and Glick, 2004). The high expression of SNAP23 on d 7 of lactation was confirmed by Western blotting (Figure 3). Thus, the firm identification and quantitative changes in SNAP23, syntaxin 3, along with several of the Rab in purified MFGM, provide a foundation of proteins likely key for the study and understanding of secretory processes in the cow.

A number of proteins were differentially expressed in the MFGM of $\mathrm{d} 7 \mathrm{MFGM}$ compared with colostrum MFGM whose functions have been associated with protection of the cow or calf from infections (Nonnecke and Smith, 1984; Hamosh et al., 1999; Mather et al., 2001; Patton, 2001; Paape et al., 2002; Cavaletto et al., 2004; Goldammer et al., 2004; Strandberg et al., 2005; Nemchinov et al., 2006; Reinhardt and Lippolis, 2006). In this class of proteins, mucin 15 and mucin 1 were the only antiinfection proteins upregulated in d 7 MFGM compared with colostrum MFGM. They were also the 2 proteins with the greatest change at greater than 7 -fold up in d 7 milk (Table 1). The TLR 2, CD59, CD14, lactadherin, and TLR 4 were unchanged using the criteria of (Ross et al., 2004; Table 2). Western blot data (Figure 3 ) for TLR2 clearly show that this protein is upregulated 1.7 -fold in the MFGM from $d$ 7 of lactation, which matches the results found with the iTRAQ method. This and other data discussed indicated that the Ross et al. (2004) cutoffs for protein changes are on the conservative side. There was some indication that TLR 4 is downregulated, but that conclusion will have to wait for specific antibodies for this protein. Clusterin and lactoferrin, which are known to decline in lactation (Nonnecke and Smith, 1984), were downregulated 2.8-fold in d 7 MFGM compared with colostrum MFGM.

\section{CONCLUSIONS}

These data demonstrate that quantitative shotgun proteomics has great potential to provide new insights into mammary development. It is yielding new information about MFGM proteome and more importantly the apical membrane of the secretory cell with the ultimate goal of new hypothesis-driven research into lactation biology. Development of methods to deplete major MFGM proteins will greatly increase the numbers of proteins identified in the MFGM.

\section{ACKNOWLEDGMENTS}

We thank Tera Nyholm, Katie Bradshaw, Derrel Hoy, and Duane Zimmerman (Periparturient Diseases of Cattle Research Unit) for their technical assistance and animal care.

\section{REFERENCES}

Bonifacino, J. S., and B. S. Glick. 2004. The mechanisms of vesicle budding and fusion. Cell 116:153-166.

Cavaletto, M., M. G. Giuffrida, and A. Conti. 2004. The proteomic approach to analysis of human milk fat globule membrane. Clin. Chim. Acta 347:41-48.

Charlwood, J., S. Hanrahan, R. Tyldesley, J. Langridge, M. Dwek, and P. Camilleri. 2002. Use of proteomic methodology for the characterization of human milk fat globular membrane proteins. Anal. Biochem. 301:314-324.

Chen, X., A. K. Walker, J. R. Strahler, E. S. Simon, S. L. TomanicekVolk, B. B. Nelson, M. C. Hurley, S. A. Ernst, J. A. Williams, and P. C. Andrews. 2006. Organellar proteomics: Analysis of pancreatic zymogen granule membranes. Mol. Cell. Proteomics 5:306-312.

Daniels, K. M., K. E. Webb, Jr., M. L. McGilliard, M. J. Meyer, M. E. Van Amburgh, and R. M. Akers. 2006. Effects of body weight and nutrition on mammary protein expression profiles in Holstein heifers. J. Dairy Sci. 89:4276-4288.

Davies, C. R., J. S. Morris, M. R. Griffiths, M. J. Page, A. Pitt, T. Stein, and B. A. Gusterson. 2006. Proteomic analysis of the mouse mammary gland is a powerful tool to identify novel proteins that are differentially expressed during mammary development. Proteomics 6:5694-5704.

DeSouza, L., G. Diehl, M. J. Rodrigues, J. Guo, A. D. Romaschin, T. J. Colgan, and K. W. Siu. 2005. Search for cancer markers from endometrial tissues using differentially labeled tags iTRAQ and cICAT with multidimensional liquid chromatography and tandem mass spectrometry. J. Proteome Res. 4:377-386.

Fortunato, D., M. G. Giuffrida, M. Cavaletto, L. P. Garoffo, G. Dellavalle, L. Napolitano, C. Giunta, C. Fabris, E. Bertino, A. Coscia, and A. Conti. 2003. Structural proteome of human colostral fat globule membrane proteins. Proteomics 3:897-905.

Fujiki, Y., A. L. Hubbard, S. Fowler, and P. B. Lazarow. 1982. Isolation of intracellular membranes by means of sodium carbonate treatment: application to endoplasmic reticulum. J. Cell Biol. 93:97-102.

Goldammer, T., H. Zerbe, A. Molenaar, H. J. Schuberth, R. M. Brunner, S. R. Kata, and H. M. Seyfert. 2004. Mastitis increases mammary mRNA abundance of beta-defensin 5, Toll-like-receptor 2 (TLR2), and TLR4 but not TLR9 in cattle. Clin. Diagn. Lab. Immunol. 11:174-185.

Gu, S., J. Chen, K. M. Dobos, E. M. Bradbury, J. T. Belisle, and X. Chen. 2003. Comprehensive proteomic profiling of the membrane constituents of a Mycobacterium tuberculosis strain. Mol. Cell. Proteomics 2:1284-1296.

Hamosh, M., J. A. Peterson, T. R. Henderson, C. D. Scallan, R. Kiwan, R. L. Ceriani, M. Armand, N. R. Mehta, and P. Hamosh. 1999. Protective function of human milk: The milk fat globule. Semin. Perinatol. 23:242-249. 
Heid, H. W., M. Schnolzer, and T. W. Keenan. 1996. Adipocyte differentiation-related protein is secreted into milk as a constituent of milk lipid globule membrane. Biochem. J. 320:10251030.

Hu, J., J. Qian, O. Borisov, S. Pan, Y. Li, T. Liu, L. Deng, K. Wannemacher, M. Kurnellas, C. Patterson, S. Elkabes, and H. Li. 2006. Optimized proteomic analysis of a mouse model of cerebellar dysfunction using amine-specific isobaric tags. Proteomics 6:4321-4334.

Jacobs, J. M., H. M. Mottaz, L. R. Yu, D. J. Anderson, R. J. Moore, W. N. Chen, K. J. Auberry, E. F. Strittmatter, M. E. Monroe, B. D. Thrall, D. G. Camp II, and R. D. Smith. 2004. Multidimensional proteome analysis of human mammary epithelial cells. J. Proteome Res. 3:68-75.

Keenan, T. W. 2001. Milk lipid globules and their surrounding membrane: A brief history and perspectives for future research. J. Mammary Gland Biol. Neoplasia 6:365-371.

Keshamouni, V. G., G. Michailidis, C. S. Grasso, S. Anthwal, J. R. Strahler, A. Walker, D. A. Arenberg, R. C. Reddy, S. Akulapalli, V. J. Thannickal, T. J. Standiford, P. C. Andrews, and G. S. Omenn. 2006. Differential protein expression profiling by iTRAQ-2DLC-MS/MS of lung cancer cells undergoing epithelialmesenchymal transition reveals a migratory/invasive phenotype. J. Proteome Res. 5:1143-1154.

Lippolis, J. D., B. D. Peterson-Burch, and T. A. Reinhardt. 2006. Differential expression analysis of proteins from neutrophils in the periparturient period and neutrophils from dexamethasonetreated dairy cows. Vet. Immunol. Immunopathol. 111:149-164.

Lippolis, J. D., and T. A. Reinhardt. 2005. Proteomic survey of bovine neutrophils. Vet. Immunol. Immunopathol. 103:53-65.

Martin, S., K. Driessen, S. J. Nixon, M. Zerial, and R. G. Parton. 2005. Regulated localization of Rab18 to lipid droplets: Effects of lipolytic stimulation and inhibition of lipid droplet catabolism. J. Biol. Chem. 280:42325-42335.

Mather, I. H. 2000. A review and proposed nomenclature for major proteins of the milk-fat globule membrane. J. Dairy Sci. 83:203-247.

Mather, I. H., L. J. Jack, P. J. Madara, and V. G. Johnson. 2001. The distribution of MUC1, an apical membrane glycoprotein, in mammary epithelial cells at the resolution of the electron microscope: Implications for the mechanism of milk secretion. Cell Tissue Res. 304:91-101.

Mather, I. H., and T. W. Keenan. 1998a. Origin and secretion of milk lipids. J. Mammary Gland Biol. Neoplasia 3:259-273.

Mather, I. H., and T. W. Keenan. 1998b. The cell biology of milk secretion: Historical notes. Introduction. J. Mammary Gland Biol. Neoplasia 3:227-232.

McManaman, J. L., C. A. Palmer, R. M. Wright, and M. C. Neville. 2002. Functional regulation of xanthine oxidoreductase expression and localization in the mouse mammary gland: Evidence of a role in lipid secretion. J. Physiol. 545:567-579.

McManaman, J. L., T. D. Russell, J. Schaack, D. J. Orlicky, and H. Robenek. 2007. Molecular determinants of milk lipid secretion. J. Mammary Gland Biol. Neoplasia 12:259-268.

Moritz, R. L., H. Ji, F. Schutz, L. M. Connolly, E. A. Kapp, T. P. Speed, and R. J. Simpson. 2004. A proteome strategy for fractionating proteins and peptides using continuous free-flow electrophoresis coupled off-line to reversed-phase high-performance liquid chromatography. Anal. Chem. 76:4811-4824.

Nemchinov, L. G., M. J. Paape, E. J. Sohn, D. D. Bannerman, D. S. Zarlenga, and R. W. Hammond. 2006. Bovine CD14 receptor produced in plants reduces severity of intramammary bacterial infection. FASEB J. 20:1345-1351.

Nonnecke, B. J., and K. L. Smith. 1984. Biochemical and antibacterial properties of bovine mammary secretion during mammary involution and at parturition. J. Dairy Sci. 67:2863-2872.

Nordstrom, E. A., M. Ryden, E. C. Backlund, I. Dahlman, M. Kaaman, L. Blomqvist, B. Cannon, J. Nedergaard, and P. Arner. 2005. A human-specific role of cell death-inducing DFFA (DNA fragmentation factor-alpha)-like effector A(CIDEA) in adipocyte lipolysis and obesity. Diabetes 54:1726-1734.
Ogg, S. L., A. K. Weldon, L. Dobbie, A. J. Smith, and I. H. Mather. 2004. Expression of butyrophilin (Btn1a1) in lactating mammary gland is essential for the regulated secretion of milk-lipid droplets. Proc. Natl. Acad. Sci. U.S.A. 101:10084-10089.

Ozeki, S., J. Cheng, K. Tauchi-Sato, N. Hatano, H. Taniguchi, and T. Fujimoto. 2005. Rab18 localizes to lipid droplets and induces their close apposition to the endoplasmic reticulum-derived membrane. J. Cell Sci. 118:2601-2611.

Paape, M., J. Mehrzad, X. Zhao, J. Detilleux, and C. Burvenich. 2002 Defense of the bovine mammary gland by polymorphonuclear neutrophil leukocytes. J. Mammary Gland Biol. Neoplasia 7:109-121

Pappin, D. J., P. Hojrup, and A. J. Bleasby. 1993. Rapid identification of proteins by peptide-mass fingerprinting. Curr. Biol. 3:327332

Park, Z. Y., and D. H. Russell. 2000. Thermal denaturation: A useful technique in peptide mass mapping. Anal. Chem. 72:2667-2670.

Park, Z. Y., and D. H. Russell. 2001. Identification of individual proteins in complex protein mixtures by high-resolution, highmass-accuracy MALDI TOF-mass spectrometry analysis of insolution thermal denaturation/enzymatic digestion. Anal. Chem. 73:2558-2564.

Parrish, D. B., G. H. Wise, J. S. Hughes, and F. W. Atkeson. 1950. Properties of the colostrum of the dairy cow. V. Yield, specific gravity and concentrations of total solid and its various components of colostrum and early milk. J. Dairy Sci. 33:457-465.

Patterson, S. D., and R. H. Aebersold. 2003. Proteomics: The first decade and beyond. Nat. Genet. 33(Suppl.):311-323.

Patton, S. 2001. MUC1 and MUC-X, epithelial mucins of breast and milk. Adv. Exp. Med. Biol. 501:35-45.

Peirce, M. J., R. Wait, S. Begum, J. Saklatvala, and A. P. Cope. 2004. Expression profiling of lymphocyte plasma membrane proteins. Mol. Cell. Proteomics 3:56-65.

Prapong, S., T. A. Reinhardt, J. P. Goff, and R. L. Horst. 2005 Short communication: $\mathrm{Ca}^{2+}$-adenosine triphosphatase protein expression in the mammary gland of periparturient cows. J. Dairy Sci. 88:1741-1744.

Pucci-Minafra, I., S. Fontana, P. Cancemi, G. Alaimo, and S. Minafra. 2002. Proteomic patterns of cultured breast cancer cells and epithelial mammary cells. Ann. N. Y. Acad. Sci. 963:122-139.

Quaranta, S., M. G. Giuffrida, M. Cavaletto, C. Giunta, J. GodovacZimmermann, B. Canas, C. Fabris, E. Bertino, M. Mombro, and A. Conti. 2001. Human proteome enhancement: High-recovery method and improved two-dimensional map of colostral fat globule membrane proteins. Electrophoresis 22:1810-1818.

Reed, J. C., K. Doctor, A. Rojas, J. M. Zapata, C. Stehlik, L. Fiorentino, J. Damiano, W. Roth, S. Matsuzawa, R. Newman, S. Takayama, H. Marusawa, F. Xu, G. Salvesen, and A. Godzik. 2003 Comparative analysis of apoptosis and inflammation genes of mice and humans. Genome Res. 13:1376-1388.

Reinhardt, T. A., A. G. Filoteo, J. T. Penniston, and R. L. Horst. 2000. $\mathrm{Ca}(2+)$-ATPase protein expression in mammary tissue. Am. J. Physiol. Cell Physiol. 279:C1595-C1602.

Reinhardt, T. A., R. L. Horst, and W. R. Waters. 2004a. Characterization of Cos-7 cells overexpressing the rat secretory pathway Ca2+-ATPase. Am. J. Physiol. Cell Physiol. 286:C164-C169.

Reinhardt, T. A., and J. D. Lippolis. 2006. Bovine milk fat globule membrane proteome. J. Dairy Res. 73:406-416.

Reinhardt, T. A., J. D. Lippolis, G. E. Shull, and R. L. Horst. 2004b. Null mutation in the gene encoding plasma membrane $\mathrm{Ca}^{2+}$ ATPase isoform 2 impairs calcium transport into milk. J. Biol. Chem. 279:42369-42373.

Ross, P. L., Y. N. Huang, J. N. Marchese, B. Williamson, K. Parker, S. Hattan, N. Khainovski, S. Pillai, S. Dey, S. Daniels, S. Purkayastha, P. Juhasz, S. Martin, M. Bartlet-Jones, F. He, A. Jacobson, and D. J. Pappin. 2004. Multiplexed protein quantitation in Saccharomyces cerevisiae using amine-reactive isobaric tagging reagents. Mol. Cell. Proteomics 3:1154-1169.

Russell, W. K., Z. Y. Park, and D. H. Russell. 2001. Proteolysis in mixed organic-aqueous solvent systems: Applications for peptide mass mapping using mass spectrometry. Anal. Chem. 73:2682-2685. 
Strandberg, Y., C. Gray, T. Vuocolo, L. Donaldson, M. Broadway, and R. Tellam. 2005. Lipopolysaccharide and lipoteichoic acid induce different innate immune responses in bovine mammary epithelial cells. Cytokine 31:72-86.

Vorbach, C., A. Scriven, and M. R. Capecchi. 2002. The housekeeping gene xanthine oxidoreductase is necessary for milk fat droplet enveloping and secretion: Gene sharing in the lactating mammary gland. Genes Dev. 16:3223-3235.

Wu, C. C., K. E. Howell, M. C. Neville, J. R. Yates III, and J. L. McManaman. 2000a. Proteomics reveal a link between the endoplasmic reticulum and lipid secretory mechanisms in mammary epithelial cells. Electrophoresis 21:3470-3482.

Wu, C. C., J. R. Yates III, M. C. Neville, and K. E. Howell. 2000b. Proteomic analysis of two functional states of the Golgi complex in mammary epithelial cells. Traffic 1:769-782.

Zerial, M., and H. McBride. 2001. Rab proteins as membrane organizers. Nat. Rev. Mol. Cell Biol. 2:107-117.

Zhou, Z., S. Yon Toh, Z. Chen, K. Guo, C. P. Ng, S. Ponniah, S. C. Lin, W. Hong, and P. Li. 2003. Cidea-deficient mice have lean phenotype and are resistant to obesity. Nat. Genet. 35:49-56. 